A method for allocation according to the economic behaviour in the EU-ETS for by-products used in cement industry

\author{
Journal Article \\ Author(s): \\ Habert, Guillaume \\ Publication date: \\ 2013-01
}

Permanent link:

https://doi.org/10.3929/ethz-b-000059347

Rights / license:

In Copyright - Non-Commercial Use Permitted

Originally published in:

The International Journal of Life Cycle Assessment 18(1), https://doi.org/10.1007/s11367-012-0464-1 


\title{
A method for allocation according to the economic behaviour in the EU-ETS for by-products used in cement industry
}

\author{
Guillaume Habert
}

Received: 15 January 2010 / Accepted: 14 June 2012 /Published online: 6 July 2012

(C) Springer-Verlag 2012

\begin{abstract}
Purpose The most efficient way to reduce the environmental impact of cement production is to replace Portland cement with alternative cementitious materials. These are most often industrial waste such as blast-furnace slags (GBFS) and coal combustion fly ashes (FA). However, a recent European directive no longer considers these products as waste but as by-products. Therefore, the impact of their production has to be considered. Within this new framework, this study develops an evaluation method of their environmental impacts.

Method This paper presents pre-existing methods and underlines their limits. Through our evaluation of these methods, it has become clear that the allocation procedure is necessary; however, results depend highly on the chosen allocation procedure. This study presents a new allocation method, based on the fact that both cement and the alternative materials, GBFS and FA, are produced by energyintensive industries (cement iron and coal) which are all subjected to the European Union Greenhouse Gas Emission Trading System. In this carbon trading system, it is economically beneficial for industries to reduce their environmental impact, like for when, by example, byproducts from one industry are used as alternative 'green' material by another industry. Our allocation coefficient is calculated so that the economic gains and losses are the same for all of the industries involved in these exchanges and provides the overall environmental benefit of the exchanges.

Results and discussion The discussion shows that whilst this method has much in common with other allocation
\end{abstract}

Responsible editor: Hans-Jürgen Garvens

G. Habert $(\square)$

IFSTTAR, Materials Department, Université Paris-Est,

Swiss Federal Institute Zurich (ETHZ) Wolfgang-Pauli Str. 15,

8093 Zürich, Switzerland

e-mail: habert@ibi.baug.ethz.ch methods, it is more accurate as it allocates the environmental costs fairly over the industries involved and is more robust because of its constant value. One of its limits is that it cannot be used for life cycle inventories; however, we test the possibility of choosing a coefficient from one impact category and applying it to all the others.

Conclusion Lastly, the technical term of the equation this paper presents could be employed for consequential life cycle assessment, to calculate the most environmental uses by-products could be put to.

Keywords Allocation · By-products · Cement · EU-ETS . LCA $\cdot$ Mineral additions

\section{Introduction}

Concrete is the most widely used construction material. It is currently estimated that the production is the equivalent of over one concrete cubic meter per person and per year (Gartner 2004). Concrete is made up from cement, water, sand and gravel. In most commercially produced concrete mixes, cement is the most polluting element. It is responsible for in between 74 and $81 \%$ of the concrete industry's $\mathrm{CO}_{2}$ emissions (Flower and Sanjayan 2007). It is also considered that the industry's $\mathrm{CO}_{2}$ emissions make up between 5 and $7 \%$ of all anthropogenic $\mathrm{CO}_{2}$ emissions (UNSTATS 2010; Friedlingstein et al. 2010). To reduce their environmental impact, cement and concrete industries increasingly need to replace Ordinary Portland Cement with alternative cementitious materials. Most of the time, these are two industrial by-products: granulated blast-furnace slags (GBFS) from iron blast furnaces or coal combustion fly ashes (FA) from coal power plants (Huntzinger and Eatmon 2009; Habert et al. 2010). This study focuses on these two supplementary cementitious materials (SCM) as they represent the majority of the mineral additions used in 
cement. Other important SCM are limestone filler and natural pozzolans (Habert et al. 2010), but they are not waste from other industries and therefore do not raise the same problems addressed here. GBFS and FA have lower environmental impacts than cement if they are considered as waste from the iron or coal industries (Gartner 2004; Kawai et al. 2005; Flower and Sanjayan 2007; Xing et al. 2008). However, a recent European Union directive (EU 2008) notes that: 'a substance or object, resulting from a production process, the primary aim of which is not the production of that item, may be regarded as not being waste but as being a by-product only if the following conditions are met: a) further use of the substance or object is certain; b) the substance or object can be used directly without any further processing other than normal industrial practice; c) the substance or object is produced as an integral part of a production process; and d) further use is lawful, i.e. the substance or object fulfils all relevant product, environmental and health protection requirements for the specific use and will not lead to overall adverse environmental or human health impacts'. This directive is very relevant to the use of SCMs such as GBFS and FA. Therefore in Europe these two materials can no longer be considered as waste but instead as by-products. Hence, the question is what is the environmental cost of these by-products?

The life cycle assessment (LCA) methodology evaluates the environmental impact of processes and products during their life cycle, from cradle to grave. It is based on the international standard ISO 14040 (ISO 2006). LCA has been used in the building sector since 1990 (Fava 2006) and is now a widely used methodology (Asif et al. 2007; Ortiz et al. 2008). According to ISO standards, when a production system produces more than one product, it is necessary to attribute an environmental burden to each product. To do so, the ISO standards provide different solutions and order in which they should be tested to see if they are applicable. First of all, this method consists in trying to avoid allocation by dividing or expanding the system in question. Then, if allocation is inevitable, physical causality, such as mass or energetic value should be used to allocate the environmental burden. Last of all, if the above solutions are not applicable, other causalities, such as economic value can be used. A previous study shows that the first solution, system expansion or diminution, was not appropriate to the cement industry (Chen et al. 2010). It showed that allocation was necessary for by-products from the steel and coal power industry. The choice of allocation procedure has proven to be one of the most controversial methodological issues in LCA, largely because it can significantly influence the results of a study (e.g. Reap et al. 2008a; Weidema 2001; Ekvall and Finnveden 2001; Frichknecht 2000). For the cement industry, the results are drastically different depending on the allocation procedure chosen (Chen et al. 2010). This study aims to provide an allocation method for the environmental impacts of different SCMs that provides a reasonably low environmental burden for by-products.

In this study, the proposed allocation method is based on the European Union Greenhouse Gas Emission Trading System (EU-ETS) which aims at limiting $\mathrm{CO}_{2}, \mathrm{NO}_{x}$ and perfluorocarbon emissions of energy intensive industries through greenhouse gas emissions trading (EU 2009). Actually, it is interesting to note that most of the industrial activities that are submitted to the EU-ETS are either part of the cement industry or related to it through the fact that cement industry is using their waste. Table 1 shows the different industrial activities from the Annex 1 of the directive and provides a reference for each waste used in cement industry. As GBFS and FA are the most commonly used SCMs, the study will however still focus on iron and coal industries whilst keeping in mind that the present study could then be extended to all the other industrial activities that are included in the Annex I of the EU directive.

The allocation method chosen in this study is calculated so that the economic gains and losses are the same for all of the industries involved in the trading of byproducts and underlines the overall environmental benefit of the exchanges.

\section{System description}

This study only addresses the first part of cement and SCM's life cycles, during their production. However, the restrictive focus on cradle-to-gate is justified because regardless of their composition all concretes have similar end life cycles, from gate-to-grave. Concerning the lifespan, we assume that cement or clinker substitution aims to reduce the environmental burden of concrete whilst achieving equivalent strength and durability performances. Therefore, all future comparisons in this paper take into account the EN 206-1 standards (AFNOR 2004) under which mix-design concrete incorporating SCMs perform as well as concrete made with ordinary Portland cement. The study does not consider concrete with substitution rates above $50 \%$, as they represent a minority of the concrete currently produced. Their high carbonation rate leads to lower durability properties (e.g. Osborne 1999; Sisomphon and Franke 2007; Habert and Roussel 2009). In this study, the comparison is made in order that SCM and cement provide the same mechanical properties. The functional unit used is then a mass of SCM that provides the same mechanical properties as $1 \mathrm{~kg}$ of cement. To do so, the EN 206-1 standard (AFNOR 2004) defines an equivalent binding capacity for 
Table 1 Industrial activities that are submitted to the European trading scheme on greenhouse gas emissions and their relations with the cement industry

\begin{tabular}{|c|c|c|c|}
\hline Activities & $\begin{array}{l}\text { Greenhouse } \\
\text { gases }\end{array}$ & $\begin{array}{l}\text { Waste used in } \\
\text { cement industry }\end{array}$ & Reference \\
\hline $\begin{array}{l}\text { Combustion of fuels in installations with a total rated thermal } \\
\text { input exceeding } 20 \mathrm{MW} \text { (except in installations for the } \\
\text { incineration of hazardous or municipal waste) }\end{array}$ & $\mathrm{CO}_{2}$ & $\begin{array}{l}\text { Fly ash }+ \text { refused } \\
\text { derived fuel ashes }\end{array}$ & $\begin{array}{l}\text { Chang et al. (1999) and } \\
\text { Barbosa et al. (2011) }\end{array}$ \\
\hline Refining of mineral oil & $\mathrm{CO}_{2}$ & Refused derived fuels & Karstensen (2008) \\
\hline Production of coke & $\mathrm{CO}_{2}$ & $\begin{array}{l}\text { Linked to coke } \\
\text { combustion (fly ash) }\end{array}$ & Sheng et al. (2007) \\
\hline $\begin{array}{l}\text { Metal ore (including sulphide ore) roasting or sintering, } \\
\text { including pelletisation }\end{array}$ & $\mathrm{CO}_{2}$ & Tailings & Yi et al. (2009) \\
\hline $\begin{array}{l}\text { Production of pig iron or steel (primary or secondary fusion) } \\
\text { including continuous casting, with a capacity exceeding } \\
2.5 \text { tonnes per hour }\end{array}$ & $\mathrm{CO}_{2}$ & $\begin{array}{l}\text { Granulated Blast furnace } \\
\text { slag and steel slags }\end{array}$ & $\begin{array}{l}\text { Kourounis et al. (2007) and } \\
\text { Schneider et al. (2011) }\end{array}$ \\
\hline $\begin{array}{l}\text { Production or processing of ferrous metals (including } \\
\text { ferro-alloys) where combustion units with a total rated } \\
\text { thermal input exceeding } 20 \mathrm{MW} \text { are operated. Processing } \\
\text { includes, inter-alia, rolling mills, re-heaters, annealing } \\
\text { furnaces, smitheries, foundries, coating and pickling }\end{array}$ & $\mathrm{CO}_{2}$ & $\begin{array}{r}\text { SiMn slag and Mn } \\
\text { oxide filter cakes }\end{array}$ & Frias and Rodriguez, (2008) \\
\hline Production of primary aluminium & $\mathrm{CO}_{2}+\mathrm{PFc}$ & Dross/sludge/red mud & $\begin{array}{l}\text { Pera et al. (1997) and Ewais } \\
\text { et al. (2009) }\end{array}$ \\
\hline $\begin{array}{l}\text { Production of secondary aluminium where combustion } \\
\text { units with a total rated thermal input exceeding } 20 \mathrm{MW} \\
\text { are operated }\end{array}$ & $\mathrm{CO}_{2}$ & $\begin{array}{l}\text { Non-metallic products } \\
\text { and salts }\end{array}$ & Shinzato and Hypolito (2005) \\
\hline $\begin{array}{l}\text { Production or processing of non-ferrous metals, including } \\
\text { production of alloys, refining, foundry casting, etc., where } \\
\text { combustion units with a total rated thermal input (including } \\
\text { fuels used as reducing agents) exceeding } 20 \mathrm{MW} \text { are operated }\end{array}$ & $\mathrm{CO}_{2}$ & Slags & Shi et al. (2008) \\
\hline $\begin{array}{l}\text { Production of cement clinker in rotary kilns with a production } \\
\text { capacity exceeding } 500 \text { tonnes/day or in other furnaces with } \\
\text { a production capacity exceeding } 50 \text { tonnes/day }\end{array}$ & $\mathrm{CO}_{2}$ & Cement industry & \\
\hline $\begin{array}{l}\text { Production of lime or calcination of dolomite or magnesite in } \\
\text { rotary kilns or in other furnaces with a production capacity } \\
\text { exceeding } 50 \text { tonnes/day }\end{array}$ & $\mathrm{CO}_{2}$ & Cement industry & \\
\hline $\begin{array}{l}\text { Manufacture of glass including glass fibre with a melting } \\
\text { capacity exceeding } 20 \text { tonnes/day }\end{array}$ & $\mathrm{CO}_{2}$ & Waste glass & $\begin{array}{l}\text { Shi and Zheng (2007) and } \\
\text { Asokan et al. (2009) }\end{array}$ \\
\hline $\begin{array}{l}\text { Manufacture of ceramic products by firing, in particular roofing } \\
\text { tiles, bricks, refractory bricks, tiles, stoneware or porcelain, } \\
\text { with a production capacity exceeding } 75 \text { tonnes/day }\end{array}$ & $\mathrm{CO}_{2}$ & $\begin{array}{l}\text { Fired bricks waste, waste } \\
\text { gypsum }\end{array}$ & $\begin{array}{l}\text { Escalante-García et al. (2009) } \\
\text { and Pereira-de-Oliveira } \\
\text { et al. (2012) }\end{array}$ \\
\hline $\begin{array}{l}\text { Manufacture of mineral wool insulation material using glass, } \\
\text { rock or, slag with a melting capacity exceeding } 20 \text { tonnes/day }\end{array}$ & $\mathrm{CO}_{2}$ & Rock wool waste & Chen et al. (2011) \\
\hline $\begin{array}{l}\text { Drying or calcination of gypsum or production of plaster } \\
\text { boards and other gypsum products, where combustion units } \\
\text { with a total rated thermal input exceeding } 20 \mathrm{MW} \text { are operated }\end{array}$ & $\mathrm{CO}_{2}$ & $\begin{array}{l}\text { Linked to cement industry: } \\
\text { calcium sulphoaluminate } \\
\text { clinker }\end{array}$ & Kuryatnyk et al. (2010) \\
\hline Production of pulp from timber or other fibrous materials & $\mathrm{CO}_{2}$ & Wood saw dust, wood fibres & $\begin{array}{l}\text { Toledo Filho et al. (2000) } \\
\text { and Turgut (2007) }\end{array}$ \\
\hline $\begin{array}{l}\text { Production of paper or cardboard with a production } \\
\text { capacity exceeding } 20 \text { tonnes/day }\end{array}$ & $\mathrm{CO}_{2}$ & Paper sludge & Pera and Amrouz (1998) \\
\hline Production of carbon black involving the carbonisation & $\mathrm{CO}_{2}$ & Carbon black & Chan and $\mathrm{Wu}(2000)$ \\
\hline
\end{tabular}

of organic substances such as oils, tars, cracker and distillation residues, where combustion units with a total rated thermal input exceeding $20 \mathrm{MW}$ are operated

Production of nitric acid

Production of adipic acid

Production of glyoxal and glyoxylic acid

Production of ammonia

Production of bulk organic chemicals by cracking, reforming, partial or full oxidation or by similar processes, with a production capacity exceeding 100 tonnes/day

$\mathrm{CO}_{2}+\mathrm{NO}_{x} \quad$ No known use in cement industry

$\mathrm{CO}_{2}+\mathrm{NO}_{x}$ No known use in cement industry

$\mathrm{CO}_{2}+\mathrm{NO}_{x} \quad$ No known use in cement industry

$\mathrm{CO}_{2} \quad$ No known use in cement industry

$\mathrm{CO}_{2} \quad$ No known use in cement industry

$\mathrm{CO}_{2} \quad$ No known use in cement industry 
Table 1 (continued)

\begin{tabular}{llll}
\hline Activities & $\begin{array}{l}\text { Greenhouse } \\
\text { gases }\end{array}$ & $\begin{array}{l}\text { Waste used in } \\
\text { cement industry }\end{array}$ & Reference \\
\hline $\begin{array}{l}\text { Production of hydrogen }\left(\mathrm{H}_{2}\right) \text { and synthesis gas by reforming } \\
\text { or partial oxidation with a production capacity exceeding } \\
25 \text { tonnes/day }\end{array}$ & & \\
$\begin{array}{l}\text { Production of soda ash }\left(\mathrm{Na}_{2} \mathrm{CO}_{3}\right) \text { and sodium bicarbonate } \\
\quad(\mathrm{NaHCO})\end{array}$ & $\mathrm{CO}_{2}$ & No known use in cement industry \\
$\begin{array}{l}\text { Capture of greenhouse gases from installations covered by this } \\
\begin{array}{l}\text { Directive for the purpose of transport and geological storage in a } \\
\text { storage site permitted under Directive 2009/31/EC }\end{array}\end{array}$ & $\mathrm{CO}_{2}$ & Linked to cement industry & ECRA (2009) \\
$\begin{array}{l}\text { Transport of greenhouse gases by pipelines for geological storage } \\
\text { in a storage site permitted under Directive 2009/31/EC }\end{array}$ & $\mathrm{CO}_{2}$ & Linked to cement industry & ECRA (2009) \\
$\begin{array}{l}\text { Geological storage of greenhouse gases in a storage site permitted } \\
\text { under Directive 2009/31/EC }\end{array}$ & $\mathrm{CO}_{2}$ & Linked to cement industry & ECRA (2009) \\
$\begin{array}{l}\text { Aviation: flights which depart from or arrive in an aerodrome situated } \\
\text { in the territory of a Member State to which the Treaty applies }\end{array}$ & $\mathrm{CO}_{2}$ & No known use in cement industry \\
\hline
\end{tabular}

For each industrial activity, the type of waste that are used in cement industry is indicated

additions when they are substituted to type I cement, as defined below:

$\mathrm{BE}=\mathrm{cem}+k \cdot \mathrm{SCM}$

Where $\mathrm{BE}$ is the binding equivalent value (in equivalents per kilogramme per cubic metre), based on the targeted strength properties of the cement concrete, "cem" is the CEM I cement dosage (in kilogrammes per cubic metre), SCM is the dosage of SCM (in kilogrammes per cubic metre), and $k$ is the coefficient specific of the additive (no unit). The $k$ parameter equals to 0.6 and 0.9 , for FA and GBFS, respectively, which means that $1 \mathrm{~kg}$ of fly ash will have the same properties as $0.6 \mathrm{~kg}$ of CEM I and that $1 \mathrm{~kg}$ of granulated blast furnace slag will be equivalent to $0.9 \mathrm{~kg}$ of cement.
The boundaries of the system are presented in Fig. 1. A first option is to consider the three industrial sectors independently which is the case in most current studies (e.g. Flower and Sanjayan 2007). In this context, the system "cement production" refers to the production of fuels and raw materials needed to produce clinker, the emissions on cement kiln and then the processes associated with the production of cement (grinding and production of gypsum). The system "coal powered electricity production" refers to the extraction and processing of coal and the coal power plant's emissions. The last system concerning "steel production" takes into account the extraction of raw materials, their processing in the blast furnace and the further transformations to produce steel.
Fig. 1 Detail of studied system. The whole system includes the production of steel, electricity and cement. It can be considered either as a unique system that has to reduce its $\mathrm{CO}_{2}$ emissions either as three distinct systems that are submitted to $\mathrm{CO}_{2}$ quotas emissions and between which exists exchange of by-products associated with a $\mathrm{CO}_{2}$ weight

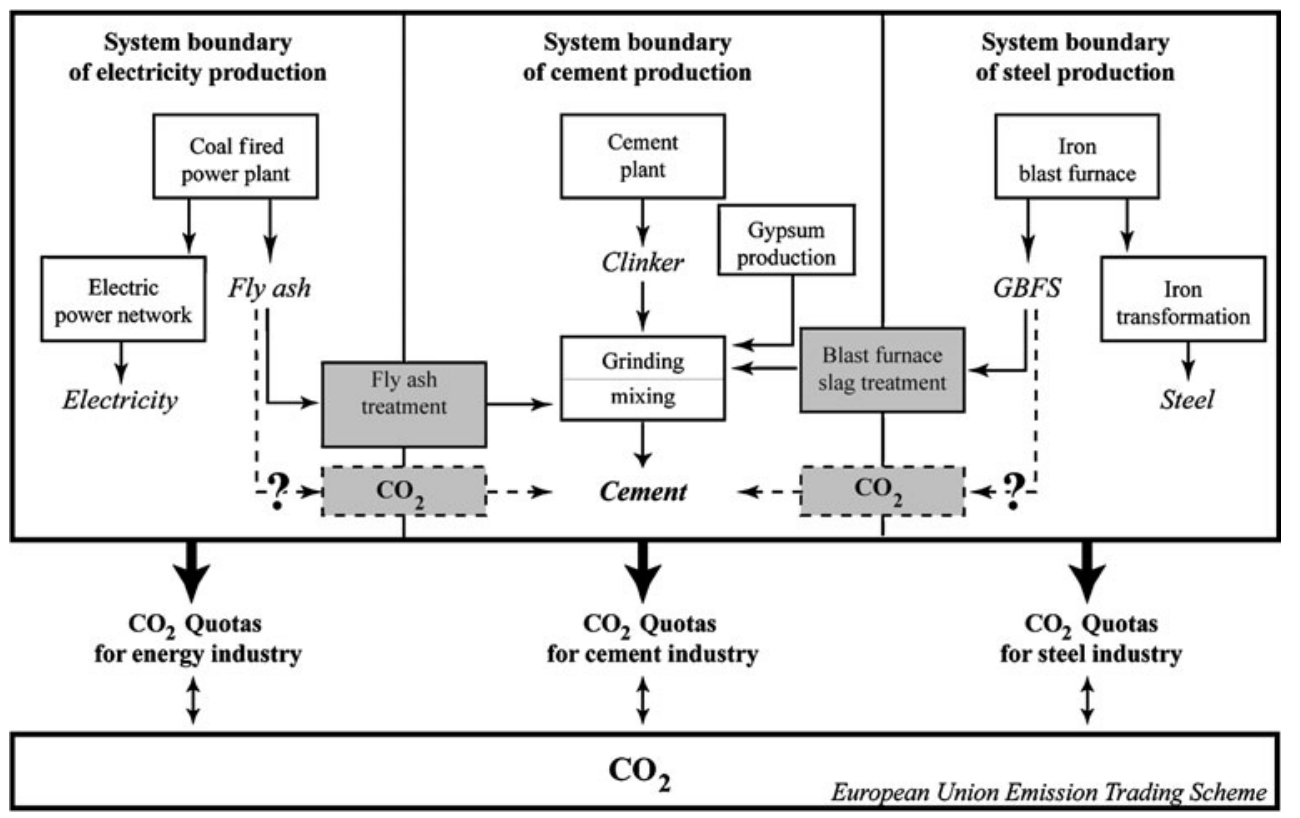


When the three systems are considered independently, it is difficult to attribute the environmental burden of the byproducts issued from the steel and electricity industry (see Fig. 1). The burden needs to be split between the original main product and the by-product. Different ways of taking into account the particular environmental burden of these products include Flower and Sanjayan (2007) who consider FA and GBFS used in cement production as waste from other industries. On the contrary Lee and Park (2005) who studied iron production as an individual system considered GBFS as a product from the iron industry which by replacing cement prevent additional cement production.

Neither option appears satisfactory. This study instead of considering the industries one by one considers all three as a system. This allows it to determine the appropriate environmental burdens of by-products used in the cement industry. This perspective is backed up by current EU regulations on greenhouse gas emissions trading which also consider the three industries as a whole.

\section{Allocation method}

\subsection{Description of allocation methods used for cement}

In the literature, many different allocation methods have been used to assess the impact of by-products both when they are produced and when they are transformed to be used in cement industry. Most of the authors (Kawai et al. 2005) attribute all of the environmental impact of the treatment of by-products to the by-products because they are being transformed specifically to be used in the cement and concrete industry. These authors respect SETAC recommendations (Lundie et al. 2007): first to avoid allocation procedure, they divide the system between a treatment process specific to by-products and a primary process common to main product and by-product; secondly, they apply the allocation procedure to the original industrial production which in this case is a multi-output process. Therefore the general presentation of the inventory allocation is as follows:

$\bar{I}_{\mathrm{SCM}}=c \cdot \bar{I}_{\text {primary_process }}+\bar{I}_{\text {treatment }}$

$\bar{I}$ is a vector that refers to the environmental impacts of $\mathrm{SCM}, C$ is the allocation coefficient that permits to attribute a percentage of the primary process impacts to the byproduct. Note that in this study impacts rather than flow inventories are allocated, contrary to ISO 14040 standards. However, as the transformation from the environmental inventory to the environmental impacts correspond to a matrix that could be referred as a technology matrix (Heijungs 1994), allocation on impacts or flow produced the same results. This assumption will be discussed later in this paper.
A common allocation mode is an allocation by mass value (ISO 2006). This procedure is often discarded because it attributes less impact to the main product due to the important mass of by-products, even though the value of the main product is the primary reason for the existence of the industry (Ekvall and Finnveden 2001). For an allocation by mass value, the allocation coefficient can be calculated with Eq. 3.

$C_{m}=\frac{m_{\mathrm{SCM}}}{m_{\text {product }}+m_{\mathrm{SCM}}}$

Where $m$ is the mass of the materials. This allocation method provides an equivalent importance for the main product and the SCM. SCMs are then considered as coproducts from the primary industry. A previous study shows that with this allocation method the environmental impact of SCM are much higher than for ordinary Portland cement which is not reasonable as the use of these SCM as cement allows a true emission reduction (Chen et al. 2010).

Another allocation mode is an allocation by economic value. It has already been used in civil engineering study to evaluate the environmental impacts of fine sand in gravel quarries (Schuurmans et al. 2005). It is often used in other industrial sectors as it highlights the driving forces of the industry (Ayer et al. 2007; Basset-Mens and van der Werf 2005; Ziegler and Hanson 2003). The allocation coefficient can be calculated with Eq. 4.

$C_{e}=\frac{(€ . m)_{S C M}}{(€ . m)_{\text {product }}+(€ . m)_{S C M}}$

Where $(€ \cdot m)$ is the multiplication of mass produced and mass value of the materials. Eq. 4 evidences that the environmental impact of SCM is related to the percentage of the industry benefits coming from selling SCM products. This percentage is expressed as the product of the mass and the price of the SCM compared with the total benefits. This method assesses then the relative benefit for the industry to sell the two products. However, this method induces a variability of impacts due to price variations.

Finally, these methods are restricted to the system where products and by-products are produced. It does not take into account the benefits for the other industry to use these waste. In other words, in Fig. 1, these allocation methods separate the whole system into three distinct systems (cement, iron and coal). In these systems, allocation methods are developed to share environmental impacts of the primary processes between main product and by-product, but no consideration about the whole system and mutual benefits are presented.

Other studies have considered that an appropriate method to calculate the environmental burdens of by-product would be to consider also the avoided burdens. This substitution 
method is not clearly mentioned in the ISO standards; however, several authors (Tillman et al. 1994; Heijungs and Guinée 2007) have shown that system expansion, which is mentioned in ISO 14040 and the substitution method are conceptually equivalent. With this method, Babbitt and Lindner (2008) calculate life cycle inventories for coal combustion fly ash by removing the environmental burdens of the clinker production that has been avoided by fly ash substitution. With this method, the allocation problem is not avoided. Actually, Babbitt and Lindner (2008) consider FA as waste, but a mass allocation method has been chosen in similar studies (Benetto et al. 2004; Lee and Park 2005). Furthermore, considering avoided burden to evaluate the environmental burden from cradle to gate can induce a double counting if this evaluation is introduced later in another LCA. Actually, system expansion method can be used in consequential LCA and within this framework it is coherent for the study of one product or one by-product and its different potential use (Thomassen et al. 2008). However, in the present study, the objective is to perform an attributional LCA and with this method, system expansion does not respect mass conservation. For instance, if the impact of a concrete product made with a mix of sand, cement and FA is calculated with the respective LCA from cradle to gate of sand, cement and FA production, and that the FA production already consider a cement substitution, the mass conservation is not preserved. Therefore, a simple substitution method or a pure allocation method does not seem to be adapted to the specific context of construction material production.

\subsection{Proposed method for global warming impact}

In this study, it is proposed to consider the specificity of cement market in the European Union. Actually in the European Union elements such as FA or GBFS are considered as by-product due to the EU directive on waste (EU 2008) and a EU-ETS has been implemented since 2003. In this context cement, energy and iron and steel sectors are subjected to the same EU-ETS, and therefore, when FA or GBFS are substituted to cement it permits to the cement industry to avoid $\mathrm{CO}_{2}$ emissions. Within the EU-ETS, cement industry has then $\mathrm{CO}_{2}$ emission quotas avoided which can be sold on the market. However, if an environmental burden is associated to SCM these emissions will be counted for the cement industry (that will have less $\mathrm{CO}_{2}$ quotas to sell) and subtracted to the primary industry (energy or iron and steel) that will then have $\mathrm{CO}_{2}$ emission quotas to sell. Depending on the allocation coefficient that is applied to FA and GBFS, the $\mathrm{CO}_{2}$ burden and its associated price will be different. In this study, it is therefore proposed to choose the allocation coefficient in order to have similar benefits for the industrial sectors involved.

The cement benefits could be expressed as the relative benefit of selling a cement composed of GBFS (CEM III) compared with selling an Ordinary Portland Cement (CEM I). This relative benefit is the sum of the relative price differences between CEM III and CEM I and the relative benefits due to the raw material production, the production of the product and the $\mathrm{CO}_{2}$ price.

The cement benefits is expressed by the Eq. 5

$$
\begin{aligned}
& \text { Cement }_{\text {benefit }}=\left(€_{\text {CEMIII }}-k . €_{C E M I}\right)+\left(k . €_{\text {stone }}-€_{G B F S}\right) \\
& +\left(k . €_{\text {kiln }}-€_{\text {treatment }}\right)+\left(k \cdot I_{C E M I} . €_{C_{2}}-C_{G B F S} . I_{\text {Iron }} . €_{C_{2}}\right)
\end{aligned}
$$

Where $€_{\mathrm{CEM} \mathrm{III}}$ is the price of $1 \mathrm{~kg}$ of CEM III compared with the price of a mass of CEM I that provides the same mechanical properties $\left(k \cdot €_{\mathrm{CEM}}\right) \cdot k \cdot \epsilon_{\text {stone }}$ is related to the avoided extraction cost of raw materials (limestone and clays) compared with the price cement industry has to buy GBFS $\left(€_{\mathrm{GBFS}}\right) . k \cdot €_{\mathrm{kiln}}$ includes the price of burning raw materials to $1,500{ }^{\circ} \mathrm{C}$ to produce clinker compared with have to vitrify and grind slags $\left(€_{\text {treatment }}\right)$. Note that even if clinker has to be grinded to produce cement, slags have to be grinded harder than clinker which induces a higher grinding cost. $I_{\mathrm{CEM}} \mathrm{I}_{\mathrm{I}}$ is the global warming potential of $1 \mathrm{~kg}$ of cement and $\epsilon_{\mathrm{CO} 2}$ is the price of $1 \mathrm{~kg}$ of $\mathrm{CO}_{2}$ on the EU-ETS. k.I $\mathrm{I}_{\mathrm{CEMI}} \epsilon_{\mathrm{CO} 2}$ refers then to the price of $\mathrm{CO}_{2}$ quotas that can be sold due to the use of GBFS instead of Portland cement. Finally depending on the environmental burden associated with by-product, the cement industry inherits a certain amount of $\mathrm{CO}_{2}$. $C_{\mathrm{GBFS}}$ is the percentage of environmental impact from the primary process associated with GBFS and $I_{\text {iron }}$ is the global warming potential of the production of pig iron. $\mathrm{C}_{\mathrm{GBFS}}$. IIron. $\epsilon_{\mathrm{CO} 2}$ refers then to the price of $\mathrm{CO}_{2}$ quotas that are associated with the slags and that are not allocated to the iron anymore.

Similarly, the relative iron benefit can be expressed as Eq. 6:

Iron $_{\text {benefit }}=€_{G B F S}+€_{\text {disposal }}+C_{G B F S} \cdot I_{\text {Iron }} . €_{C_{2}}$

Where $€_{\mathrm{GBFS}}$ is the price of $1 \mathrm{~kg}$ of GBFS sold to the cement industry, $€_{\text {disposal }}$ is the avoided price for waste disposal and $\mathrm{C}_{\mathrm{GBF}}$. $\mathrm{I}_{\mathrm{Iron}} . \epsilon_{\mathrm{CO} 2}$ is the benefit from the allocation of a certain amount of $\mathrm{CO}_{2}$ to the GBFS. These $\mathrm{CO}_{2}$ emissions are associated to the cement industry and are therefore not considered to be emitted by the iron industry which is then a benefit on the EU-ETS (see Fig. 1).

The proposed allocation aims at choosing the allocation coefficient $C_{\mathrm{GBFS}}$ in order to have a similar benefit between 
cement and steel industrial sector. This can be expressed by

Eq. 7.

$C_{B F S G}=\frac{k \cdot I_{C E M I}}{2 I_{\text {Iron }}}+\frac{€_{C E M I I I}-€_{\text {disposal }}-2 €_{\text {GBFS }}-€_{\text {treatment }}+k \cdot\left(€_{\text {stone }}+€_{k i \text { ln }}-€_{C E M I}\right)}{2 I_{\text {Iron }} €_{C O_{2}}}$

The equation of the allocation coefficient can be divided in two terms: a technical parameter related to the ratio of the impact of the amount of cement that has the same mechanical properties as $1 \mathrm{~kg}$ of SCM and the impact of the multioutput process that can produce $1 \mathrm{~kg}$ of SCM, and an economical term that is related to all prices. If one considers that as the objective of cement substitution is to build a new low carbon society and that in this post-carbon society, if steel and cement are still used, the price that will keep increasing is the price of $\mathrm{CO}_{2}$. Then, the price of $\mathrm{CO}_{2}$ could be considered as infinite compared with other prices, which simplifies Eq. 7 towards an approximation that is the following:

$\lim _{\epsilon_{\mathrm{CO}_{2} \rightarrow \infty}}\left(C_{\mathrm{BFSG}}\right)=\frac{k \cdot I_{\mathrm{CEMI}}}{2 I_{\text {iron }}}$

The same reflection can be used to calculate the allocation coefficient for fly ash as the same processes are involved. The treatment of FA is only the drying and cement has to be burned and grinded instead. A generic term of the previous equation can then be:

$C_{\mathrm{SCM}}=\frac{k \cdot I_{\mathrm{CEMI}}}{2 I_{\text {primary_production }}}$

In this expression, the allocation coefficient for the global warming impact of a supplementary cementitious material can be calculated as the ratio of the impact of the cement quantity that will provide the same mechanical strength $\left(k \cdot I_{\text {CEM I }}\right)$ and the impact of the process that has produced this SCM.

\subsection{Generalisation to all other impact categories}

Considering only the technical term of the Eq. 7, and avoiding the economical term, allows to highlight an interesting aspect of the allocation procedure that could be used for all the other impact categories. Actually, the ratio of the impact of the amount of cement that has the same mechanical properties as $1 \mathrm{~kg}$ of SCM and the impact of the multioutput process that can produce $1 \mathrm{~kg}$ of SCM has an environmental meaning whatever the impact category is. When the environmental impact of cement is similar to the impact of the primary process, the allocation coefficient is low, highlighting the fact that the substitution of the cement by this SCM does not provide a significant reduction of emission between the two processes. On the contrary, when the impact of the cement production is high compared with the impact of the primary process, the allocation coefficient will be important highlighting the fact that, for this impact category, the substitution provides a true environmental improvement by avoiding the cement production. In order to perform an allocation to all the different environmental impact categories and not only to the global warming potential, Eq. 9 can be applied to all the environmental impact categories leading to a specific value for each of them. This allocation vector that has a specific value for each impact category can then be used in Eq. 2 .

\section{Application}

An application of this allocation procedure has been done for the two SCMs: FA and GBFS. The functional unit used is a mass of SCM that provides the same mechanical properties as $1 \mathrm{~kg}$ of cement. Therefore it has to be noted that $1 \mathrm{~kg}$ of CEM I is compared with $1 /$ $0.6 \mathrm{~kg}$ of fly ash and $1 / 0.9 \mathrm{~kg}$ of slag in accordance with Eq. 1.

\subsection{Inventory data and impact calculation}

The all-inclusive components are calculated with the original system boundary of the EcoInvent database (Kellenberger and Althaus 2003). A distinction has been made between the production of the main products and their by-products (iron industry and coal power plants), and the specific treatments made on the by-products for their introduction in cement or concrete. Inputs and outputs data used are presented in Tables 2 and 3. For more details, see Chen et al. (2010). Environmental impacts were evaluated using the LCA software Simapro 7.1 (Goedkoop and Oele 2004). LCA was performed according to the baseline method of CML01 (Guinnée et al. 2002) that evaluates ten environmental impacts (abiotic depletion, global warming, ozone layer depletion, fresh and marine water ecotoxicity, terrestrial ecotoxicity, human toxicity, eutrophication, acidification and photochemical oxidation). 
Table 2 Inputs for production and treatment of supplementary cementitious materials (SCM)

\begin{tabular}{|c|c|c|c|c|c|}
\hline & \multicolumn{2}{|c|}{ Production of blast furnace slag } & \multicolumn{2}{|l|}{ Production of fly ash } & \multirow[t]{2}{*}{ Production of cement } \\
\hline & \multicolumn{4}{|l|}{ Product quantity } & \\
\hline & $\begin{array}{l}\text { Pig iron }(1 \mathrm{~kg}) \\
\text { Process }\end{array}$ & GBFS $(1 \mathrm{~kg})$ & Electricity (1 kWh) & FA $(1 \mathrm{~kg})$ & CEM I (1 kg) \\
\hline & Furnace & Treatment & Coal-fired power plants & Treatment & Cement kiln \\
\hline \multicolumn{6}{|l|}{ Raw materials } \\
\hline Sinter $(\mathrm{kg})$ & 1.05 & & & & \\
\hline Pellets (kg) & 0.4 & & & & \\
\hline Lump ore $(\mathrm{kg})$ & 0.15 & & & & \\
\hline Limestone (kg) & & & & & 1.22 \\
\hline Clay $(\mathrm{kg})$ & & & & & 0.31 \\
\hline Gypsum (kg) & & & & & $1 \cdot 10^{-2}$ \\
\hline Water $\left(\mathrm{m}^{3}\right)$ & & 0.01 & 0.035 & & $2 \cdot 10^{-4}$ \\
\hline \multicolumn{6}{|l|}{ Energy } \\
\hline Hard coal (kg) & 0.49 & & 0.432 & & $9.8 \cdot 10^{-3}$ \\
\hline Electricity (kWh) & 0.1 & $7.2 \cdot 10^{-2}$ & & $6.82 \cdot 10^{-3}$ & $1.3 \cdot 10^{-1}$ \\
\hline Petroleum coke $(\mathrm{kg})$ & & & & & $4.5 \cdot 10^{-2}$ \\
\hline Gaz (MJ) & & $3.16 \cdot 10^{-1}$ & & 0.29 & $2.3 \cdot 10^{-2}$ \\
\hline Heavy fuel oil (kg) & & & & & $1.6 \cdot 10^{-2}$ \\
\hline Light distillates (kg) & & & & & $1.3 \cdot 10^{-2}$ \\
\hline Waste (MJ) & & & & & 1.2 \\
\hline Fuel $\left(\mathrm{m}^{3}\right)$ & & $1.14 \cdot 10^{-6}$ & $1.73 \cdot 10^{-4}(\mathrm{~kg})$ & $1.03 \cdot 10^{-6}$ & \\
\hline \multicolumn{6}{|l|}{ Transport } \\
\hline Boat (t km) & 1.5 & & & & $9.7 \cdot 10^{-2}$ \\
\hline Train (t km) & 0.251 & $3 \cdot 10^{-3}$ & $5.09 \cdot 10^{-3}$ & & $1.22 \cdot 10^{-2}$ \\
\hline Truck (t km) & 0.01 & $5.3 \cdot 10^{-3}$ & & $3 \cdot 10^{-3}$ & $5.7 \cdot 10^{-2}$ \\
\hline \multicolumn{6}{|l|}{ Installation (Unit) } \\
\hline Blast furnace & $1.33 \cdot 10^{-11}$ & & & & \\
\hline Coal thermal plant & & & $1.33 \cdot 10^{-11}$ & & \\
\hline Cement plant & & & & & $6.0 \cdot 10^{-11}$ \\
\hline
\end{tabular}

Values set in italics are related to primary production system. Values set in bold are related to treatment processes made in order to incorporate the $\mathrm{SCM}$ in cement or concrete. The production of $1 \mathrm{~kg}$ of cement is presented. See text for references

\subsection{Results}

The environmental impacts of the different processes are presented in Table 4. Note that the impacts of the process that produces SCM are calculated for $1 \mathrm{~kg}$ of by-product. It is therefore different than if it was the impact for $1 \mathrm{~kg}$ of pig iron and $1 \mathrm{kWh}$ of coal powered electricity respectively. The impacts shown in Table 3 are used to calculate the allocation coefficient in order to affect a percentage of the primary process for the by-product (Eq. 2). Results with the proposed allocation of environmental impacts between main products and by-products are presented in Fig. 2 for the ten impact categories. Figure 2 shows that with this allocation procedure the environmental impact of SCM are lower than cement, but not negligible. For FA, they are close to
$50 \%$ of cement impacts for most impact categories. For GBFS, the impacts are similar than FA for global warming potential, abiotic depletion and ozone layer depletion, but they are higher for the other impact categories. For ecotoxicities, GBFS have higher impacts than cement.

\section{Discussion}

\subsection{Comparison to other allocation method}

In this study a new allocation procedure has been proposed. To evaluate the pertinence of this assumption, the results should be compared with other possibilities. The allocation coefficient with an allocation by mass value is $19.4 \%$ as 
Table 3 Outputs for production and treatment of SCM

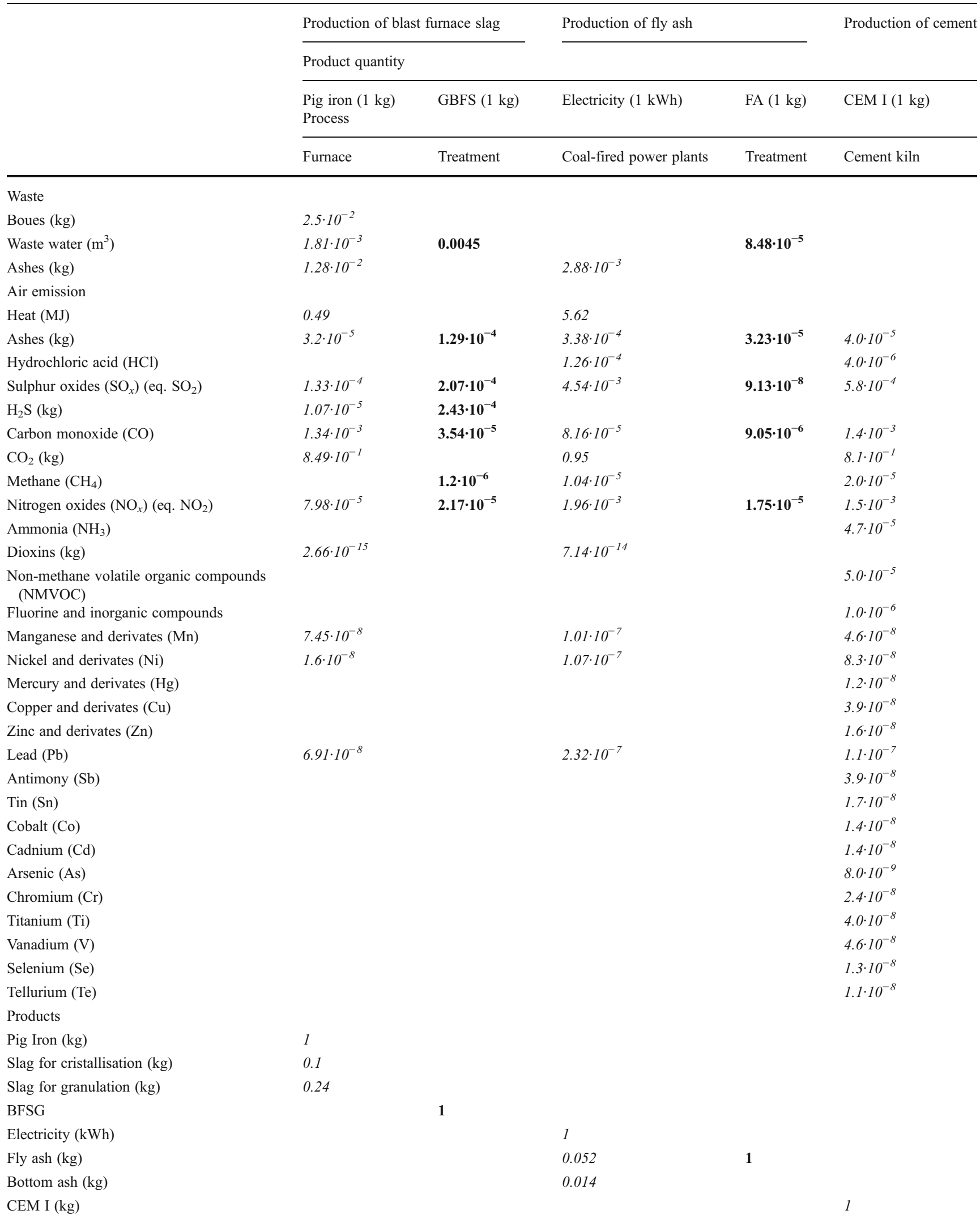

Values set in italics are related to primary production system. Values set in bold are related to treatment processes made in order to incorporate the $\mathrm{SCM}$ in cement or concrete. The production of $1 \mathrm{~kg}$ of cement is presented. See text for references 
Table 4 Environmental impacts of SCM for the different CML01 indicators

\begin{tabular}{|c|c|c|c|c|c|}
\hline Impact category & $\begin{array}{l}\text { Pig iron production } \\
\text { (1 kg GBFS) }\end{array}$ & $\begin{array}{l}\text { BFSG Treatment } \\
(1 \mathrm{~kg} \text { GBFS })\end{array}$ & $\begin{array}{l}\text { Electricity production } \\
(1 \mathrm{~kg} \text { FA })\end{array}$ & $\begin{array}{l}\text { FA treatment } \\
(1 \mathrm{~kg} \mathrm{FA})\end{array}$ & $\begin{array}{l}\text { Cement } \\
\text { production } \\
(1 \mathrm{~kg} \mathrm{CEM} \mathrm{I})\end{array}$ \\
\hline Abiotic depletion (kg Sb eq.) & $6.19 \cdot 10^{-2}$ & $2.88 \cdot 10^{-4}$ & $1.58 \cdot 10^{-1}$ & $2.02 \cdot 10^{-4}$ & $1.59 \cdot 10^{-3}$ \\
\hline Global warming (GWP100; $\mathrm{kg} \mathrm{CO}_{2}$ eq.) & 6.51 & $1.69 \cdot 10^{-2}$ & 20.50 & $5.26 \cdot 10^{-3}$ & $8.44 \cdot 10^{-1}$ \\
\hline Ozone layer depletion (kg CFC-11 eq.) & $1.07 \cdot 10^{-7}$ & $4.11 \cdot 10^{-9}$ & $1.72 \cdot 10^{-7}$ & $3.35 \cdot 10^{-9}$ & $2.28 \cdot 10^{-8}$ \\
\hline Human toxicity (kg 1,4-DB eq.) & 2.06 & $8.24 \cdot 10^{-3}$ & 4.09 & $1.58 \cdot 10^{-3}$ & $4.02 \cdot 10^{-2}$ \\
\hline Fresh water aquatic ecotoxicity ( $\mathrm{kg} 1,4-\mathrm{DB}$ eq.) & 1.04 & $1.92 \cdot 10^{-3}$ & $2.59 \cdot 10^{-1}$ & $1.76 \cdot 10^{-4}$ & $4.14 \cdot 10^{-3}$ \\
\hline Marine aquatic ecotoxicity (kg 1,4-DB eq.) & $2.68 \cdot 10^{3}$ & 10.0 & $2.43 \cdot 10^{4}$ & 1.93 & $1.94 \cdot 10^{1}$ \\
\hline Terrestrial ecotoxicity (kg 1,4-DB eq.) & $1.69 \cdot 10^{-2}$ & $1.42 \cdot 10^{-4}$ & $3.66 \cdot 10^{-2}$ & $1.68 \cdot 10^{-5}$ & $1.17 \cdot 10^{-3}$ \\
\hline Photochemical oxidation ( $\mathrm{kg} \mathrm{C}_{2} \mathrm{H}_{4}$ eq.) & $4.33 \cdot 10^{-3}$ & $1.59 \cdot 10^{-5}$ & $5.41 \cdot 10^{-3}$ & $1.93 \cdot 10^{-6}$ & $4.26 \cdot 10^{-5}$ \\
\hline Acidification ( $\mathrm{kg} \mathrm{SO}_{2}$ eq.) & $2.37 \cdot 10^{-2}$ & $3.46 \cdot 10^{-4}$ & $1.57 \cdot 10^{-1}$ & $3.32 \cdot 10^{-5}$ & $1.15 \cdot 10^{-3}$ \\
\hline Eutrophication ( $\mathrm{kg} \mathrm{PO}_{4}{ }^{2-}$ eq.) & $3.51 \cdot 10^{-3}$ & $1.05 \cdot 10^{-5}$ & $8.63 \cdot 10^{-3}$ & $4.94 \cdot 10^{-6}$ & $1.73 \cdot 10^{-4}$ \\
\hline
\end{tabular}

All the impacts are calculated related to $1 \mathrm{~kg}$ of SCM produced. See text for references

$0.24 \mathrm{~kg}$ of GBFS is produced for each kilogramme of pig iron produced. The economic allocation can be based on a ratio between a slag price (40 to $90 €$ ) and a price from pig iron $(150 € / \mathrm{t})$ or steel $(1,500 € / \mathrm{t})$ depending on the material considered. It leads therefore to different allocation coefficients that range between 0.6 and $12.6 \%$. Finally if GBFS are considered as a waste, the allocation coefficient is null. Figure 3 presents different values for GBFS. It shows that the proposed allocation is lower than a mass allocation, which is in accordance with the driving force of the society as an iron blast furnace is designed to produce pig iron and not slags.
Compared with economic allocation based on the price ratio between main product and by-product (here iron and slag), the proposed allocation procedure induces constant value for each category and Fig. 3 shows the great variability that price variations on steel can induce. Finally, the impacts are much higher than if it was considered as a waste.

\subsection{Allocation on inventory or on impact}

The main limitation of this allocation procedure is the fact that it is calculated from the environmental impacts and not
Fig. 2 Environmental impacts of a mass of FA $(1.67 \mathrm{~kg})$ and GBFS $(1.11 \mathrm{~kg})$ equivalent to the replacement of $1 \mathrm{~kg}$ of cement CEM I with the allocation proposed in the study between the different industries. Calculation are made with CML01 method

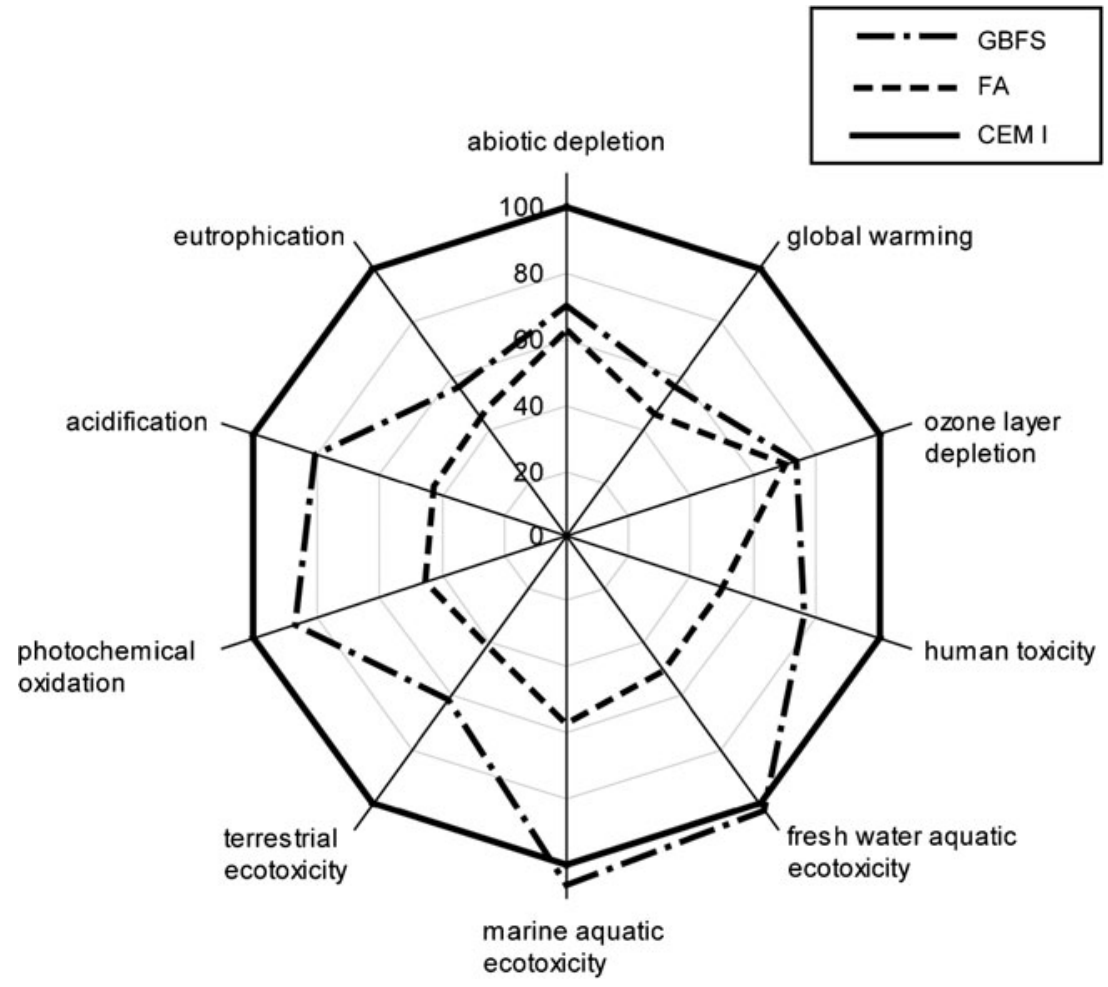




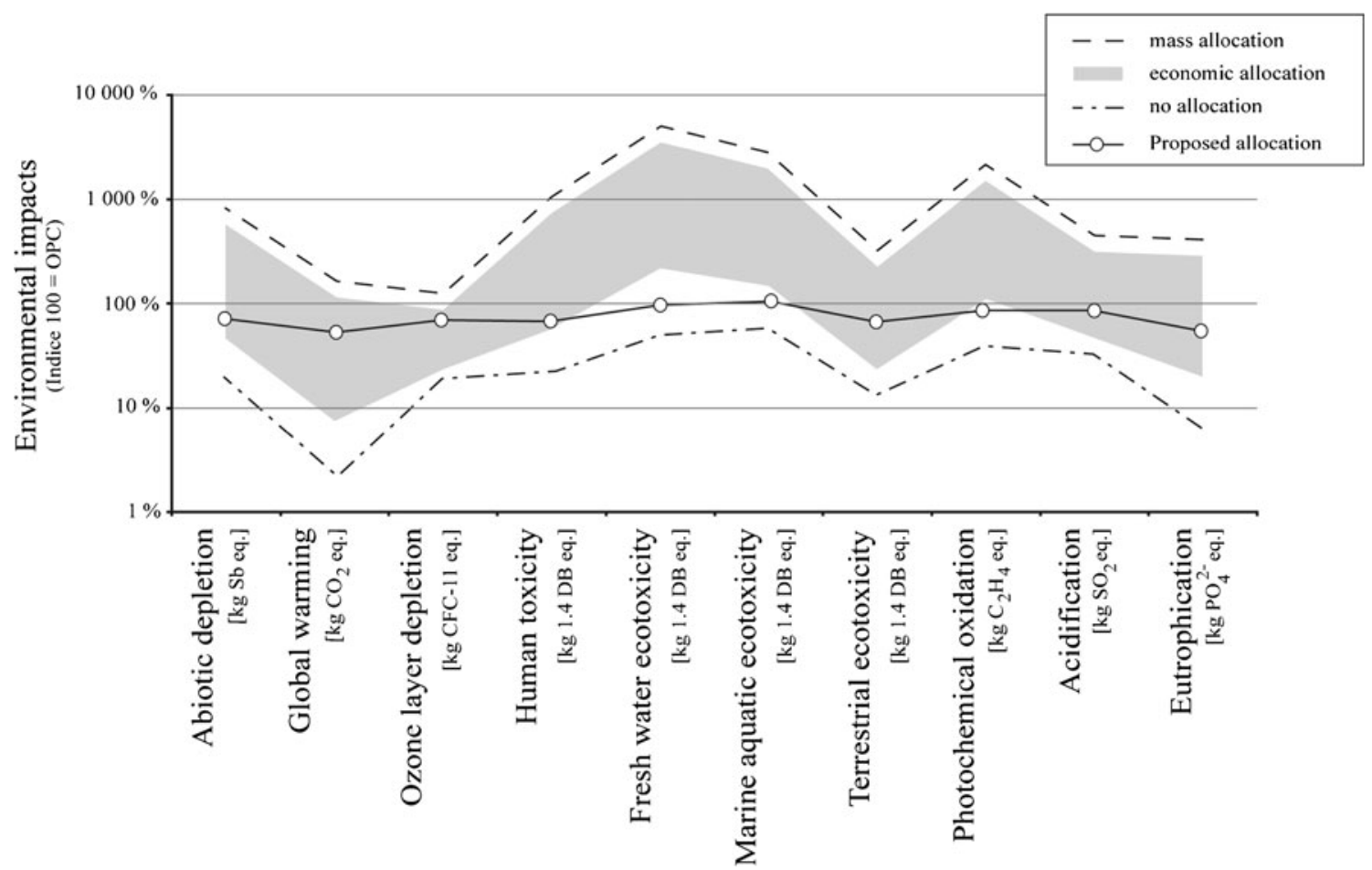

Fig. 3 Environmental impacts of $1.11 \mathrm{~kg}$ of GBFS equivalent to the replacement of $1 \mathrm{~kg}$ of cement CEM I, depending on the chosen allocation procedure. The proposed allocation is compared with the situation where no allocation is done (GBFS as a waste) and where the allocation is driven by the mass or the economic value of the GBFS. For economic evaluation different prices have been tested leading to a broad variation

percentage calculated for the global warming potential as it is actually the effective driver that pushes the cement industry to buy FA and GBFS in order to reduce the global warming impact of the cement production (Parrott 2002; Damtoft et al. 2008). Therefore, choosing this coefficient for all impact categories reflect the fact that the relative benefit of using SCM instead of Portland cement for reducing acidification or abiotic depletion is a consequence of the decision to use preferentially SCM than Portland cement for low carbon cement production. Figure 4 shows the environmental impacts of $1 \mathrm{~kg}$ of SCM when a specific allocation coefficient for each category is used and when the allocation coefficient calculated for global warming is affected to all categories. The environmental impacts of GBFS induced by an allocation coefficient based on the percentage calculated with Eq. 9 for global warming are slightly higher than the impacts calculated in a previous study for an economic allocation (Chen et al. 2010). For FA (see Fig. 4b), the allocation coefficient is exactly the same as the one calculated with an economic allocation. As a conclusion, the fact to use the global warming impact allocation coefficient calculated with our method (Eq. 9) for all the impact categories allows having environmental impacts similar to the previous one found with economic allocation but they will not be sensitive to price fluctuations anymore. 

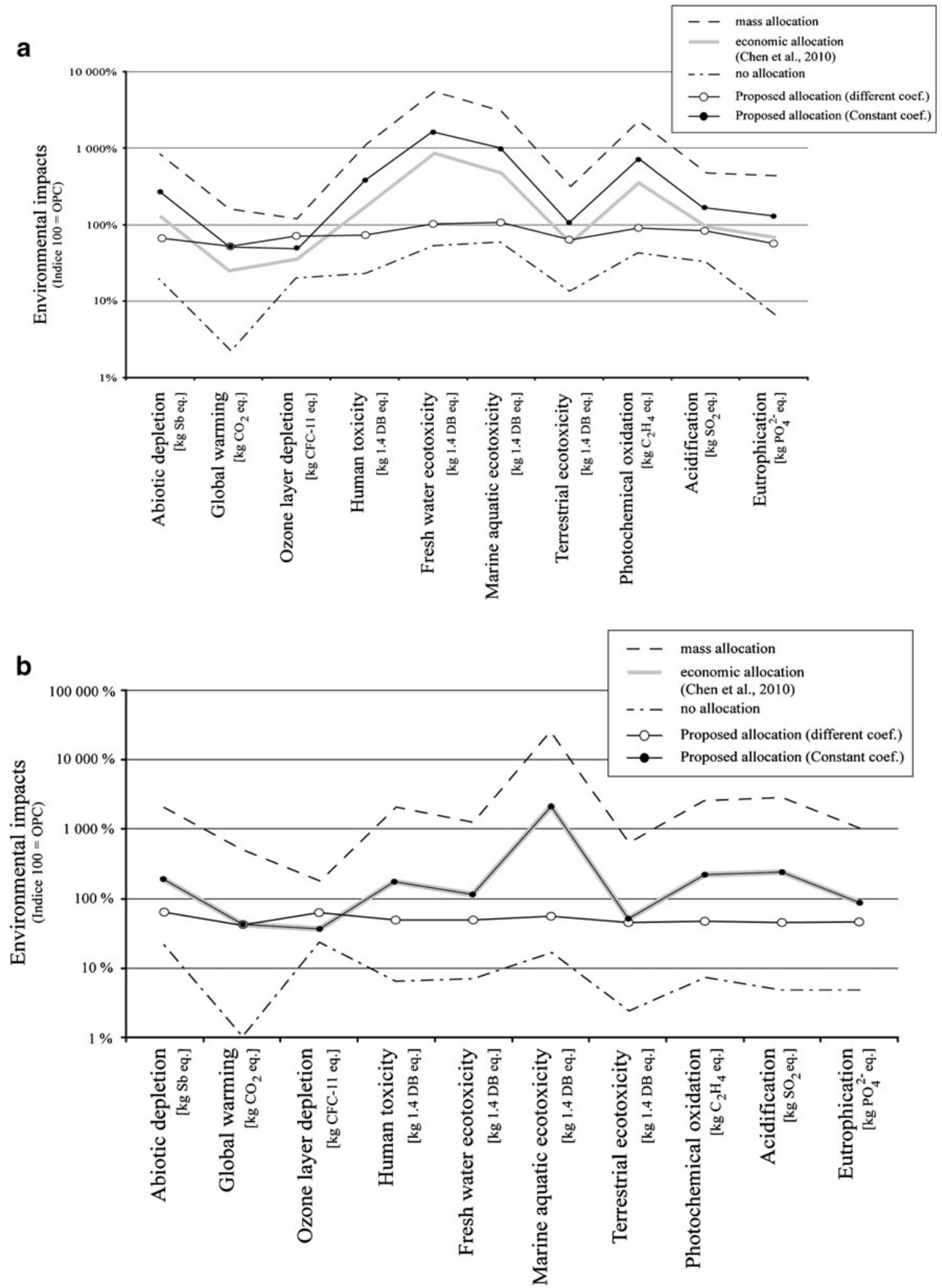

Fig. 4 Environmental impacts of SCM equivalent to the replacement of $1 \mathrm{~kg}$ of cement CEM I, depending on the chosen allocation procedure: a $1.11 \mathrm{~kg}$ of GBFS is compared with $1 \mathrm{~kg}$ of CEM I and $\mathbf{b}$ $1.67 \mathrm{~kg}$ of FA is compared with $1 \mathrm{~kg}$ of CEM I. The fair allocation proposed in this study is calculated with Eq. 9 either with a different allocation coefficient for each impact category or with the same coefficient for all categories. Economic allocation comes from Chen et al. (2010) 


\subsection{Waste management}

Lastly, the interest of this allocation coefficient, if not used as an allocation procedure, can be to evaluate in which industrial sector the use of the by-product can be the most useful from an environmental point of view. In other word, if the LCA methodology is not attributional but consequential (Thomassen et al. 2008) the upper part of the fraction in Eq. 9 will be different for each application where the byproduct is used. From the point of view of the by-product producer, it is interesting to look for the highest ratio, because the environmental load that is put on the byproduct is unloaded from its main product that has therefore an environmental advantage. Increasing this allocation coefficient can be made either by choosing the industrial sector that induces the highest ratio between the impact of the substituted material production process and the by-product production primary process. The practical application in civil engineering is to prefer using Blast furnace slag to replace cement rather than gravel for road sub-base as it is currently done. The other option is to improve the treatment process of the by-product in order to give it a high efficiency for the substitution (increasing $k$ ). This aspect can be illustrated in cement industry by the fact that there exists a large variability of FA quality leading to $k$ between 0.4 and 0.7 . Improving the process in order to improve the treatment of FA induces, with this allocation mechanism, a reduction in the environmental load of electricity which can be justified by the fact that it better replace the cement.

All these aspects should be better studied in further research as it seems that the main interest of the allocation procedure proposed in this study might not be the allocation coefficient for life cycle inventories of SCM but rather a more general interest to qualify the efficiency of waste management.

\section{Conclusions}

The allocation method proposed in this study is robust as it gives a constant value. However, if it is calculated for each impact categories, it cannot be used for the life cycle inventories. This seriously limits its use. A possibility is to choose a coefficient from one impact category and to apply it to all the others. This reduces the environmental significance of the method, but as allocation procedure do not have a true environmental significance in itself, it is not a real limitation. For the specific question of SCM in cement industry, this calculation allows to have a trend that is similar to the economic allocation calculated previously (Chen et al. 2010) but with a constant ratio independent of prices fluctuations. Finally, the technical term of the allocation coefficient calculated in this study could have an interest for consequential LCA studies. Actually, it can be used to evaluate, from an environmental point of view, in which industrial sector the use of the by-product would be the most beneficial. It could also be an incitative method to improve the treatment of this by-product in order to increase the substitution rate of the by-product.

\section{References}

AFNOR, French Normalisation Organisation (2004) NF EN 206-1 Concrete - part I: specification, performance, production and conformity. Department of Standards Malaysia, Selangor

Asif M, Muneer T, Kelley R (2007) Life cycle assessment: a case study of a dwelling home in Scotland. Build Environ 42:391-1394

Asokan P, Osamani M, Price ADF (2009) Assessing the recycling potential of glass fibre reinforced plastic waste in concrete and cement composites. J Clean Prod 17:821-829

Ayer NW, Tyedmers PH, Pelletier NL, Sonesson U, Scholz A (2007) Co-product allocation in life cycle assessments of seafood production systems: review of problems and strategies. Int $\mathrm{J}$ Life Cycle Assess 12:480-487

Babbitt CW, Lindner AS (2008) A life cycle comparison of disposal and beneficial use of coal combustion products in Florida. Part 1: methodology and inventory of materials, energy and emissions. Int J Life Cycle Assess 13:202-211

Barbosa R, Lapa N, Lopes H, Gulyurtlu I, Mendes B (2011) Stabilization/solidification of fly ashes and concrete production from bottom and circulating ashes produced in a power plant working under mono and co-combustion conditions. Waste Manag 31:2009-2019

Basset-Mens C, van der Werf HMG (2005) Scenario-based environmental assessment of farming systems: the case of pig production in France. Agric Ecosyst Environ 105:127-144

Benetto E, Rousseaux P, Blondin J (2004) Life cycle assessment of coal by-products based electric power production scenarios. Fuel 83:957-970

Chan WWJ, Wu CML (2000) Durability of concrete with high cement replacement. Cem Concr Res 30:865-879

Chang N-B, Wang HB, Huang WL, Lin KS (1999) The assessment of reuse potential for municipal solid waste and refused derived fuel incineration ashes. Resour Conserv Recycl $25: 255-270$

Chen C, Habert G, Bouzidi Y, Jullien A, Ventura A (2010) LCA allocation procedure used as an incitative method for waste recycling: an application to mineral additions in concrete. Res Cons Recycl 54:1231-1240

Chen A, Lin W-T, Huang R (2011) Application of rock wool waste in cement-based composites. Mater Design 32:635-642

Damtoft J, Lukasik J, Herfort D, Sorrentino D, Gartner E (2008) Sustainable development and climate change initiatives. Cem Concr Res 38:115-127

ECRA, European Cement Research Academy, [on-line], Carbon Capture Technology: ECRA's approach towards CCS; Communication Bulletin, 2009. Available from http://www.ecra-online.org/fileadmin/ redaktion/files/pdf/ECRA_CCS_Communication_Bulletin.pdf. Accessed 18 March 2011

Ekvall T, Finnveden G (2001) Allocation in ISO 14041-a critical review. J Clean Prod 9:197-208

Escalante-García JI, Magallanes-Rivera RX, Gorokhovsky A (2009) Waste gypsum-blast furnace slag cement in mortars with granulated slag and silica sand as aggregates. Constr Build Mater 23:2851-2855 
European Union (2008) Directive 2008/98/EC of the European parliament and of the council on waste and repealing certain directives. Official journal of the European Union, 22.11.2008, L312: 3-30

European Union (2009) Directive 2009/29/EC of the European parliament and of the council amending Directive 2003/87/EC so as to improve and extend the greenhouse gas emission allowance trading scheme of the Community. Official Journal of the European Union, 23.04.2009, L 140: 63-87

Ewais EMM, Khalil NM, Amin MS, Ahmed YMZ, Barakat MA (2009) Utilization of aluminum sludge and aluminum slag (dross) for the manufacture of calcium aluminate cement. Ceram Int 35:3381-3388

Fava JA (2006) Will the next 10 years be as productive in advancing life cycle approaches as the last 15 years? Int J Life Cycle Assess 11:6-8

Flower DJM, Sanjayan JG (2007) Greenhouse gas emissions due to concrete manufacture. Int J Life Cycle Assess 12:282-288

Frias M, Rodriguez C (2008) Effect of incorporating ferroalloy industry wastes as complementary cementing materials on the properties of blended cement matrices. Cem Concr Comp 30:212-219

Frichknecht R (2000) Allocation in life cycle inventory analysis for joint production. Int J Life Cycle Assess 5:85-95

Friedlingstein P, Houghton RA, Marland G, Hackler J, Boden TA, Conway TJ, Canadell JG, Raupach MR, Ciais P, Le Quéré C (2010) Uptake on $\mathrm{CO}_{2}$ emissions. Nat Geosci 3:811-812

Gartner E (2004) Industrially interesting approaches to "low- $\mathrm{CO}_{2}$ " cements. Cem Concr Res 34:1489-1498

Goedkoop M, Oele M (2004) Simapro database manual. Methods library. Pre consultants BV, Amersfoort

Guinée JB, Gorrée M, Heijungs R, Huppes G, Kleijn R, van Oers L, Wegener Sleeswijk A, Suh S, Udo de Haes HA, de Bruijn H, vanDuin R, Huijbregts MAJ (2002) Life cycle assessment: an operational guide to the ISO standards. Kluwer Academic Publishers, Dordrecht

Habert G, Roussel N (2009) Study of two concrete mix-design strategies to reach carbon mitigation objectives. Cem Concr Comp 31:397-402

Habert G, Billard C, Rossi P, Chen C, Roussel N (2010) Cement production technology improvement compared to factor 4 objectives. Cem Concr Res 40:820-826

Heijungs R (1994) A generic method for the identification of options for cleaner products. Ecol Econ 10:69-81

Heijungs R, Frischknecht R (1998) A special view on the nature of the allocation problem. Int J Life Cycle Assess 3:321-332

Heijungs R, Guinée JB (2007) Allocation and 'What if' scenarios in life cycle assessment of waste management systems. Waste Manag 27:997-1005

Huntzinger DN, Eatmon TD (2009) A life-cycle assessment of Portland cement manufacturing: comparing the traditional process with alternative technologies. J Clean Prod 17:668-675

ISO (2006) Environmental management-life cycle assessment-principles and framework; ISO 14040. International Standardisation Organisation

Karstensen KH (2008) Formation, release and control of dioxins in cement kilns. Chemosphere 70:543-560

Kawai K, Sugiyama T, Kobayashi K, Sano S (2005) Inventory data and case studies for environmental performance evaluation of concrete structure construction. J Adv Concr Techno 3:435-456

Kellenberger D, Althaus H-J (2003) Life cycle inventories of building products. Final report Ecoinvent, EMPA Dübendorf, Swiss Centre for Life Cycle Inventories

Kourounis S, Tsivilis S, Tsakiridis PE, Papadimitriou GD, Tsibouki Z (2007) Properties and hydration of blended cements with steelmaking slag. Cem Concr Res 37:815-822

Kuryatnyk T, Chabannet M, Ambroise J, Pera J (2010) Leaching behaviour of mixtures containing plaster of Paris and calcium sulphoaluminate clinker. Cem Concr Res 40:1149-1156

Lee K-M, Park P-J (2005) Estimation of the environmental credit for the recycling of granulated blast furnace slag based on LCA. Res Cons Recycl 44:139-151
Lundie S, Ciroth A, Huppes G (2007) Inventory methods in LCA: towards consistency and improvement. Final report. UNEPSETAC Life Cycle Initiative

Ortiz O, Castells F, Sonnemann G (2008) Sustainability in the construction industry: a review of recent developments based on LCA. Constr Build Mater 23:28-39

Osborne GJ (1999) Durability of Portland blast-furnace slag cement concrete. Cem Concr Comp 21:11-21

Parrott L (2002) Cement, Concrete and Sustainability. A report on the progress of the UK cement and concrete industry towards sustainability. Technical report, British Cement Association

Pera J, Amrouz A (1998) Development of highly reactive metakaolin from paper sludge. Adv Ceram Bas Mater 7:49-56

Pera J, Boumaza R, Ambroise J (1997) Development of a pozzolanic pigment from red mud. Cem Concr Res 27:1513-1522

Pereira-de-Oliveira LA, Castro-Gomes JP, Santos PMS (2012) The potential pozzolanic activity of glass and red-clay ceramic waste as cement mortars components. Constr Build Mater 31:197-203

Reap J, Roman F, Duncan S, Bras B (2008) A survey of unresolved problems in life cycle assessment. Part I: goals and scope and inventory analysis. Int J Life Cycle Assess 13:290-300

Schneider M, Romer M, Tschudin M, Bolio H (2011) Sustainable cement production - present and future. Cem Concr Res 41:642-650

Schuurmans A, Rouwette R, Vonk N, Broers JW, Rijnsburger HA, Pietersen HS (2005) LCA of finer sand in concrete. Int J Life Cycle Assess 10:131-135

Sheng G, Zhai J, Li Q, Li F (2007) Utilization of fly ash coming from a CFBC boiler co-firing coal and petroleum coke in Portland cement. Fuel 86:2625-2631

Shi C, Zheng K (2007) A review on the use of waste glasses in the production of cement and concrete. Resour Conserv Recycl $52: 234-247$

Shi C, Meyer C, Behnood A (2008) Utilization of copper slag in cement and concrete. Resour Conserv Recycl 52:1115-1120

Shinzato MC, Hypolito R (2005) Solid waste from aluminum recycling process: characterization and reuse of its economically valuable constituents. Waste Manag 25:37-47

Sisomphon K, Franke L (2007) Carbonation rates of concretes containing high volume of pozzolanic materials. Cem Concr Res 37:1647-1653

Teller P, Denis S, Renzoni R, Germain A, Delaisse P, d'Inverno H (2000) Use of LCI for the decision-making of a Belgian cement producer: a common methodology for accounting $\mathrm{CO}_{2}$ emissions related to the cement life cycle. 8th LCA Case Studies Symposium SETAC-Europe

Thomassen MA, Dalgaard R, Heijungs R, de Boer I (2008) Attributional and consequential LCA of milk production. Int J Life Cycle Assess 13:339-349

Tillman A-M, Ekvall T, Baumann H, Rydberg T (1994) Choice of system boundaries in life cycle assessment. J Clean Prod 2:21-29

Toledo Filho RD, Scrivener K, England GL, Ghavami K (2000) Durability of alkali-sensitive sisal and coconut fibres in cement mortar composites. Cem Concr Comp 22:127-143

Turgut P (2007) Cement composites with limestone dust and different grades of wood sawdust. Build Environ 42:3801-3807

UNSTATS (2010) Greenhouse gas emissions by sector (absolute values). United Nation Statistical Division, New York

Weidema BP (2001) Avoiding co-product allocation in life cycle assessment. J Ind Ecol 4:11-33

Xing S, Xu Z, Jun G (2008) Inventory analysis of LCA on steel- and concrete-construction office buildings. Energy Build 40:1188-1193

Yi Z-L, Sun H-H, Wei X-Q, Li C (2009) Iron ore tailings used for the preparation of cementitious material by compound thermal activation. Inter J Min Met Mater 16:355-358

Ziegler F, Hansson PA (2003) Emissions from fuel combustion in Swedish cod fishery. J Clean Prod 11:303-314 